\title{
Bronchial Biopsy Evidence for Leukocyte Infiltration and Upregulation of Leukocyte-Endothelial Cell Adhesion Molecules 6 Hours after Local Allergen Challenge of Sensitized Asthmatic Airways
}

\author{
S. Montefort, C. Gratziou, D. Goulding, R. Polosa, D. O. Haskard, ` P. H. Howarth, S. T. Holgate, and M. P. Carroll \\ Department of Immunopharmacology, University Medicine, Southampton General Hospital, Southampton SO9 $4 X Y$; \\ and *Department of Medicine, R.P.M.S., Hammersmith Hospital, London WIZ ONN, United Kingdom
}

\begin{abstract}
We have examined the mucosal changes occurring in bronchial biopsies from six atopic asthmatics 5-6 h after local endobronchial allergen challenge and compared them with biopsies from saline-challenged segments from the same subjects at the same time point. All the subjects developed localized bronchoconstriction in the allergen-challenged segment and had a decrease in forced expiratory volume in $1 \mathrm{~s}\left(\mathrm{FEV}_{1}\right)(P<0.01)$ and a decrease in their methacholine provocative concentration of agonist required to reduce $\mathrm{FEV}$, from baseline by $20 \%(P<0.05)$ $24 \mathrm{~h}$ postchallenge. At $6 \mathrm{~h}$ we observed an increase in neutrophils $(P=0.03)$, eosinophils $(P=0.025)$, mast cells $(P$ $=0.03)$, and $\mathrm{CD3}^{+}$lymphocytes $(P=0.025)$, but not in $\mathrm{CD4}^{+}$ or $\mathrm{CD8}^{+}$lymphocyte counts. We also detected an increase in endothelial intercellular adhesion molecule type $1(P<0.05)$ and $E$-selectin $(P<0.005)$, but not vascular cell adhesion molecule type 1 expression with a correlative increase in submucosal and epithelial $\mathrm{LFA}^{+}$leucocytes $(P<0.01)$. Thus, in sensitized asthmatics, local endobronchial allergen instillation leads to an increased inflammatory cell infiltrate of the airway mucosa that involves upregulation of specific adhesion molecules expressed on the microvasculature. (J. Clin. Invest. 1994. 93:14111421.) Key words: allergen • asthma • leukocytes • adhesion molecules
\end{abstract}

\section{Introduction}

Autopsies (1) and more recently bronchoscopy findings (2) have provided evidence for a major role of inflammation involving many cells, including mast cells and eosinophils, in the airway dysfunction that characterizes asthma. In addition to showing an inflammatory infiltrate (3), bronchial mucosal biopsies reveal epithelial damage $(2,4,5)$ and subepithelial collagen deposition (6). While some have found a correlation between epithelial disruption (2), mast cell activation ( 3 ), eosinophil (7), and T-cell infiltration (8) with indices of disease

Address correspondence to Dr. S. T. Holgate, Department of Immunopharmacology, University Medicine, Level D, Centre Block, Southampton General Hospital, Tremona Road, Southampton SO9 4XY, UK.

Received for publication 26 February 1993 and in revised form 25 August 1993.

J. Clin. Invest.

(C) The American Society for Clinical Investigation, Inc. $0021-9738 / 94 / 04 / 1411 / 11 \$ 2.00$

Volume 93, April 1994, 1411-1421 activity including bronchial hyperresponsiveness ( $\mathrm{BHR}),{ }^{1}$ it is not possible to assess cellular dynamics at a single time point.

Almost a quarter of a century has passed since Booij-Noord et al. (9) and Pepys and Hutchcroft (10) described two phases of airflow obstruction after allergen provocation of sensitized asthmatic airways. The early asthmatic response (EAR) begins almost immediately after allergen challenge, peaking at 15-20 min and recovering over $1-2 \mathrm{~h}$. Its IgE dependence $(11,12)$, together with the associated increase in mediator levels in plasma, bronchoalveolar lavage [BAL] (13), and urine (14), and the ability of selective antagonists of histamine, prostaglan$\operatorname{din} \mathrm{D}_{2}$, and the sulphidopeptide leukotrienes (LT) to attenuate the response, has reinforced the initial view that the EAR, like the skin wheal response to allergen, is mast cell dependent. Such a mechanism also explains the inhibitory actions of cromolyn sodium and nedocromil sodium on the EAR.

Depending on the dose of the initial challenge (15) approximately two-thirds of atopic asthmatic subjects will experience a second wave of airflow obstruction 4-8 h after challenge (16), which, in being accompanied by a progressive increase in BHR, has been regarded by some to reflect a more realistic model of allergen-related clinical asthma. This late asthmatic response (LAR) is preceded by a transient blood eosinopenia (17), and between 2 (18) and $96 \mathrm{~h}$ (19) postchallenge by an increase in neutrophils and eosinophils in BAL. While the LAR is also markedly attenuated by prior administration of cromolyn sodium $(9,10)$, corticosteroids $(9,20)$, and $\operatorname{LTD}_{4}$ antagonists (21), the cellular basis for these pharmacological effects is still not known.

Although BAL and bronchial washings can provide useful information about cellular and mediator events on the airway surface, by analogy with diseases of the lung parenchyma, it may not accurately reflect events occurring within the airway wall itself. In an attempt to overcome this difficulty we have applied fibreoptic bronchoscopy to enable local subsegmental challenge and mucosal biopsy of asthmatic airways to be undertaken. By using allergen and saline placebo delivered to separate lung segments during the same bronchoscopy procedure, each subject was able to act as his/her own control. Endobronchial subcarinal mucosal biopsies were obtained at 5-6 $\mathrm{h}$ after local allergen and saline challenge and subjected to a immuno-

1. Abbreviations used in this paper: BAL, bronchoalveolar lavage; BHR, bronchial hyperresponsiveness; EAR, early asthmatic response; $\mathrm{FEV}_{1}$, forced expiratory volume in $1 \mathrm{~s}$; GMA, glycolmethacrylate; ICAM, intercellular adhesion molecule; LAR, late asthmatic response; LT, leukotriene; $\mathrm{PC}_{20}$, provocative concentration of agonist required to reduce $\mathrm{FEV}_{1}$ from baseline by $20 \%$; VCAM, vascular cell adhesion molecule. 
histochemical analysis to provide a detailed profile of the cellular events associated with this time point.

\section{Methods}

Subjects. Six mildly symptomatic asthmatics (three male, three female; mean age $\pm S E M, 30.5 \pm 2.5 \mathrm{yr}$ ) were recruited for the study. At the time of enrolment all the asthmatic subjects had stable pulmonary function with a forced expiratory volume in $1 \mathrm{~s}\left(\mathrm{FEV}_{1}\right)$ of $>70 \%$ of that predicted for their age and height. None of the asthmatics were being treated with inhaled or oral corticosteroids, sodium cromoglycate, or theophylline. All were using the $\beta_{2}$ agonist salbutamol (albuterol) by metered dose inhaler when required for relief of symptoms. They had hyperreactive airways to inhaled methacholine with a geometric mean provocative concentration of agonist required to reduce FEV from baseline by $20 \%\left(\mathrm{PC}_{20}\right)$ of 2.51 (range, $\left.0.25-3.52\right) \mathrm{mg} / \mathrm{ml}$. The asthmatic subjects were all atopic as defined by a $>3-\mathrm{mm}$ skin wheal response to one or more of five common allergens (Dermatophagoides pteronyssinus, mixed grass pollen, dog, feathers, and cat dander (Bencard, Brentford, UK). All subjects were nonsmokers and none had experienced an upper respiratory tract infection within $6 \mathrm{wk}$ of investigations. The study conformed to the Declaration of Helsinki, was approved by the combined Southampton Hospitals and the University Ethics Subcommittee, and informed written consent was obtained from each subject.

Screening visit. Subjects attended the laboratory $5 \mathrm{~d}$ before the bronchoscopy when allergen skin prick testing, baseline spirometry, and methacholine reactivity testing were performed. The technique used for bronchial challenge was adapted from the five-breath procedure of Chai et al. (22) using an Inspiron nebulizer (CR Bard, Sunderland, UK). After recording baseline $\mathrm{FEV}_{1}$, subjects inhaled five breaths of $0.9 \%$ sodium chloride (saline) from functional residual capacity to total lung capacity from the nebulizer via a mouthpiece. Measurements of $\mathrm{FEV}_{1}$ were made at 1 and $3 \mathrm{~min}$ and, provided this value did not fall by $>10 \%$ of baseline, the methacholine provocation was undertaken. Subjects inhaled increasing doubling concentrations $(0.02-16 \mathrm{mg} / \mathrm{ml}$ saline) of methacholine [Sigma Chemical Co., Poole, Dorset, UK] at 5-7-min intervals, with measurements of $\mathrm{FEV}_{1}$ being made 1-3 min after each inhalation. The stepwise methacholine inhalations continued until the FEV , had fallen $>20 \%$ of the postsaline value. The concentration of methacholine was plotted against the percentage fall in $\mathrm{FEV}_{1}$ from postsaline baseline, and that concentration causing a $20 \%$ fall in $\mathrm{FEV}_{1}\left(\mathrm{PC}_{20}\right)$ was derived by linear interpolation of the last two data points.

The allergen extract (grass pollen or D. pteronyssinus) (Bencard, Brentford, UK) used for local bronchial challenge was that which produced the largest wheal response on skin prick testing. In each subject a skin wheal dose response was undertaken using 10-fold dilutions of allergen, and a 1:100 dilution of allergen producing a 3-mm wheal response was chosen for the local bronchial challenge and prepared in $0.9 \%$ saline.

Bronchoscopy and local challenge. Fibreoptic bronchoscopy was undertaken only if the $\mathrm{FEV}_{1}$ was $>70 \%$ of patient's predicted value and the subject's platelet count and clotting studies were within normal limits. Bronchoscopy was carried out using a standardized protocol (23). All subjects received atropine ( $0.6 \mathrm{mg}$ intramuscularly), midazolam (2-5 $\mathrm{mg}$ i.v.), and salbutamol ( $2.5 \mathrm{mg}$ by nebulization) $15 \mathrm{~min}$ before the procedure. Oxygen (100\%) was administered via nasal prongs throughout the procedure and oxygen saturation monitored with a digital oximeter (Minolta, Middlesex, UK). Fibreoptic bronchoscopy was performed with bronchoscope (IT-20; Olympus Optical Co., Tokyo, Japan). Care was taken to ensure that the larynx and upper airways were adequately anesthetized using lignocaine spray (4\%). The bronchoscope was passed through the nares, and up to $12 \mathrm{ml}$ of lignocaine ( $1 \%$ ) was introduced through the bronchoscope into the larynx and lower airways. The bronchoscope was then wedged into the anterior division of the right upper lobe (RUL) to undertake a "control" challenge with $20 \mathrm{ml}$ of sterile saline prewarmed to $37^{\circ} \mathrm{C}$. The instrument was then passed into the lateral subdivision of the right middle lobe (RML) and $20 \mathrm{ml}$ of prewarmed allergen solution instilled. $5 \mathrm{~min}$ after introduction of the two solutions the appearance of the airways was observed and photographed to record any airway narrowing. If widespread bronchoconstriction or severe localized airway narrowing occurred, $5-10 \mathrm{ml}$ of salbutamol $(2.5 \mathrm{mg} / \mathrm{ml})$ was instilled via the bronchoscope and the procedure terminated.

No specimens were taken at the first bronchoscopy but a second bronchoscopy was carried out 5-6 $\mathrm{h}$ postchallenge using the same procedure, and biopsies were taken from the two sites using alligator biopsy forceps. On completion of the procedure, subjects were observed for $3 \mathrm{~h}$ and any residual bronchoconstriction was reversed with nebulized salbutamol.

Postbronchoscopy. Since it was not possible to make an assessment of the physiological response of the airways just before the second bronchoscopy (other than $\mathrm{FEV}_{1}$ ), subjects were asked to reattend the laboratory 1,3 , and $7 \mathrm{~d}$ after the local challenges for further measurement of baseline $\mathrm{FEV}_{1}$ and methacholine $\mathrm{PC}_{20}$.

Sample processing. Mucosal biopsies, measuring $0.5-1.5 \mu \mathrm{m}$ in diameter, were gently extracted from the forceps with a hypodermic needle. One biopsy sample was placed in ice-cooled acetone containing the protease inhibitors phenylmethylsulfonyl fluoride $(2 \mathrm{nM})$ and iodoacetamide $(2 \mathrm{nM})$ and cooled rapidly to $-20^{\circ} \mathrm{C}$. The following day the sample was transferred into acetone at room temperature for $15 \mathrm{~min}$ followed by methylbenzoyl for a further $15 \mathrm{~min}$. The tissue was then immersed in glycolmethacrylate (GMA) monomer [Polysciences, Northampton, UK] at $4^{\circ} \mathrm{C}$ for $7 \mathrm{~h}$, during which time the GMA solution was changed three times. Finally, the tissue was embedded in GMA resin prepared by mixing GMA monomer $N, N$-dimethylaniline in PEG 400 and benzoyl peroxide, and polymerized overnight at $4^{\circ} \mathrm{C}$ (24). The GMA blocks were stored in air-tight containers at $-20^{\circ} \mathrm{C}$ until used for immunostaining.

A second biopsy for transmission electron microscopy was immediately placed into glutaraldehyde (3\%) for $2 \mathrm{~h}$ and then washed in caccodylate/sucrose buffer overnight. The biopsy was postfixed in $2 \%$ osmium tetroxide in caccodylate buffer for $2 \mathrm{~h}$, rinsed in millipored double-distilled water, and incubated in $2 \%$ uranyl acetate for a further $1 \mathrm{~h}$. After dehydration through graded alcohols, clearing in Histosol for 20 min, and infiltration with 50:50 Histosol/Spurr resin for $30 \mathrm{~min}$, the sample was finally infiltrated in $100 \%$ Spurr overnight. The biopsy was embedded in Spurr resin followed by centrifugation and polymerized at $60^{\circ} \mathrm{C}$ for $16 \mathrm{~h}$. 90-nm thick sections were cut using an ultramicrotome (C. Reichart, Austria), mounted on uncoated copper grids, and examined using a microscope (H7000; Hitachi, Tokyo, Japan).

Immunohistochemistry. The GMA sections were cut at $2-\mu \mathrm{m}$ thickness and floated onto ammonia water (1:500), picked onto $0.01 \%$ poly-L-lysine glass slides, and allowed to dry at room temperature for 1-6 h. Sections cut for immunostaining of endothelial cell adhesion molecules (CAMs) were sequential to enable accurate cellular localization of immunoreactivity.

Table 1. Monoclonal Antibodies Used in Immunohistochemistry

\begin{tabular}{|c|c|c|c|}
\hline Name & Raised against & Species [isotype] & Source \\
\hline $6.5 \mathrm{~B} 5$ & ICAM-1 & Mouse $\left[\operatorname{IgG}_{1}\right]$ & Dr. D. O. Haskard \\
\hline $1.2 \mathrm{~B} 6$ & E-selectin & Mouse $\left[\operatorname{IgG}_{1}\right]$ & Dr. D. O. Haskard \\
\hline $1.4 \mathrm{C} 3$ & VCAM-1 & Mouse $\left[\operatorname{IgG}_{1}\right]$ & Dr. D. O. Haskard \\
\hline $\mathrm{TS} 1 / 22$ & CD11a & Mouse $\left[\mathrm{IgG}_{1}\right]$ & Prof. T. A. Springer \\
\hline LFA1/2 & CD11a & Mouse $\left[\operatorname{IgG}_{2}\right]$ & Dr. L. Admiral \\
\hline EN4 & Endothelium & Mouse $\left[\operatorname{IgG}_{1}\right]$ & SanBio Ltd. \\
\hline EG2 & $\begin{array}{l}\text { Eosinophilic } \\
\text { cationic protein }\end{array}$ & Mouse $\left[\operatorname{IgG}_{1}\right]$ & Dako Ltd. \\
\hline CD3 & Lymphocytes & Mouse $\left[\operatorname{Ig}_{1}\right]$ & Pharmacia \\
\hline AAl & Mast cell tryptase & Mouse $\left[\operatorname{IgG}_{1}\right]$ & Dr. A. Walls \\
\hline Elastase & Neutrophil elastase & Mouse $\left[\operatorname{IgG}_{1}\right]$ & Pharmacia \\
\hline Mouse & $\begin{array}{l}\text { Immunoglobulin } \\
\text { IgG }_{1}\end{array}$ & control $\mathrm{MoAb}$ & Sigma Chemical Co. \\
\hline
\end{tabular}


Endogenous peroxidase was blocked using a solution of $0.1 \%$ sodium azide and $0.3 \%$ hydrogen peroxide, followed by three rinses in Tris-buffered saline (TBS) adjusted at $\mathrm{pH}$ 7.6. Undiluted culture supernatant consisting of $10 \%$, Dulbecco's MEM fetal calf serum, and $1 \%$ bovine serum albumin was applied for $30 \mathrm{~min}$ followed by a primary $\mathrm{mAb}$, and further incubation at room temperature overnight. The mAbs used and their sources of origin are displayed in Table I. After rinsing, biotinylated rabbit anti-mouse IgG Fab (Dako Ltd., High Wycombe, UK) was applied to the section for $2 \mathrm{~h}$ and followed by the streptavidin-biotin horseradish-peroxidase complex (Dako Ltd.) for a further $2 \mathrm{~h}$. After rinsing in TBS, amino-ethyl carbamazole (AEC) in acetate buffer ( $\mathrm{pH} 5.2$ ) and hydrogen peroxide were used as substrate to develop a peroxide-dependent red color reaction (24). The sections were counterstained with Mayer's hematoxylin.

Quantification of immunostaining. Inflammatory cells staining positively with each $\mathrm{mAb}$ were counted in the submucosa, excluding mucosal glands and blood vessels. The total area of submucosa was calculated by delineating the area of the section on a video interactive display system (VIDS2) and using software for measurement of area (Analytical Measurement Systems, Cambridge, UK), the results being expressed as the number of cells per square millimeter of submucosa. Cells staining positively for LFA-1 were also counted in five randomly chosen high-power fields of the epithelium and expressed as cells per millimeter of epithelium.

In the case of the CAMs expressed on the endothelium, we have used a technique of quantification that relates the number of blood vessels stained with a specific mAb to the total complement of the microvasculature. Briefly, the number of vessels present in the section stained with the vessel marker EN4 (SanBio, Uden, The Netherlands) was taken as the full complement of vessels present in this section (25). The number of vessels staining positive for specific adhesion molecules in consecutive sections were expressed as a percentage of the total vessel population. This index denoted the proportion of vessels expressing a particular adhesion molecule at a detectable level for a particular antibody titration used. All slides were analysed in a "blinded" fashion.

Statistical analysis. As the cell and CAM counts were not normally distributed, the Mann Whitney $U$ test was used when analyzing differences between groups, and the Wilcoxon paired rank tests for data at different time points within the same group. The Spearman's rank coefficient was used to investigate the relationship between cell counts and adhesion molecule expression.

\section{Results}

\section{Airway physiology}

Within 3-5 min, all six subjects visibly reacted to the local instillation of allergen by bronchoconstricting, the challenged segmental bronchus producing a range of airway narrowing from 30 to $95 \%$, in contradistinction to the saline-challenged control site at which there was no visible change in airway caliber. The spirometry traces obtained just before the second bronchoscopy were technically unsatisfactory in four of the six subjects on account of drowsiness from the previous sedating medication. In the two subjects who produced good records, $\mathrm{FEV}_{1} 6 \mathrm{~h}$ after local allergen and saline challenge was no different from the first prebronchoscopy $\mathrm{FEV}_{1}$. Although allergen was only instilled into one lung subsegment, it produced measurable changes in overall indices of lung function. Thus, $24 \mathrm{~h}$ after allergen instillation the mean \pm SEM predicted $\mathrm{FEV}_{1}$ fell from $100.1 \pm 4.1$ to $88.1 \pm 5.6 \%(P<0.01)$, indicative of a persistent late phase response. Further evidence of disordered airway function after allergen instillation was obtained by finding a significant $(P<0.05)$ reduction in the geometric mean methacholine $\mathrm{PC}_{20}$ from a prechallenge value of 2.51 (range, 0.253.52 ) to 1.33 (range, $0.11-2.45$ ) $\mathrm{mg} / \mathrm{ml}$ at $24 \mathrm{~h}$. However, by 7 d postchallenge both the $\mathrm{FEV}_{1}$ and $\mathrm{PC}_{20}$ had returned to base-
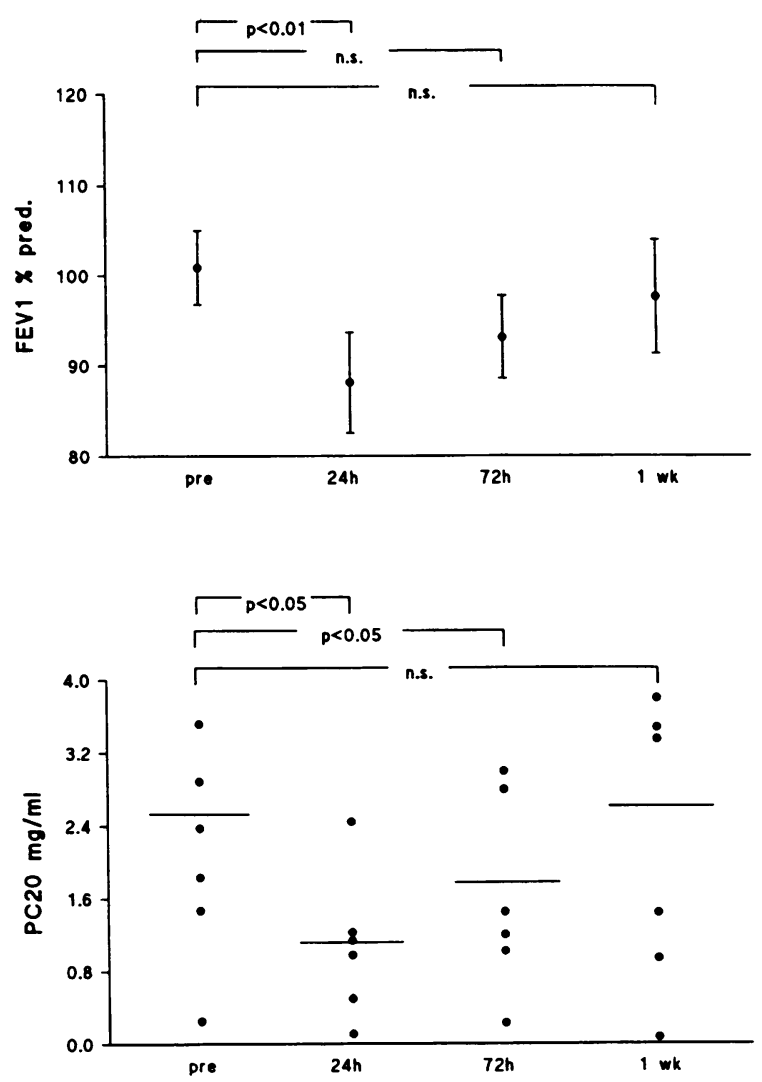

Figure 1. Changes in $(a)$ percent predicted $\mathrm{FEV}_{1}$ and $(b)$ methacholine $\mathrm{PC}_{20}$ during the various studied time points before and after the allergen challenge. Horizontal lines denote median values.

line levels of $97.8 \pm 6.31$ and $2.9 \mathrm{mg} / \mathrm{ml}$, respectively (NS) (Fig. 1).

\section{Bronchial biopsies}

\section{LEUKOCYTE PHENOTYPES}

Immunohistochemistry. The cell-specific mAbs identified a mixed inflammatory cellular infiltrate in association with the late phase response. Staining for elastase clearly demonstrated the presence of large numbers of neutrophils in the submucosa after allergen challenge (Fig. 2, $a$ and $b$ ). The median neutrophil count at the allergen-exposed site was 265.5 (range, 50$2,043) / \mathrm{mm}^{2}$ compared with 46 (range, $17-88$ ) $/ \mathrm{mm}^{2}$ at the saline-challenged site $(P<0.03)$ (Fig. 3$)$. Further inspection of the neutrophils under high-power light microscopy demonstrated a pericellular haze of elastase immunostaining indicative of its extracellular release. The number of infiltrating neutrophils correlated positively with the increase in endothelial expression of ICAM-1 $\left(r_{\mathrm{s}}=0.59\right)$ but not E-selectin $\left(r_{\mathrm{s}}\right.$ $=0.27$ ).

In addition to neutrophils, eosinophils identified immunohistochemically by their granule content of eosinophil cationic protein were also seen to infiltrate the allergen-challenged mucosa, with numbers in the saline- and allergen-challenged mucosa being 8.5 (range, 0-27) and 45.5 (range, 16-245) $/ \mathrm{mm}^{2}$, respectively $(P<0.025)$. The eosinophil increases correlated with those of the neutrophils $\left(r_{\mathrm{s}}=0.82, P<0.05\right)$, but no correlation was found with the extent of expression of any of the three CAMs. Allergen exposure also stimulated an increase in submucosal tryptase-positive mast cells from a median of 

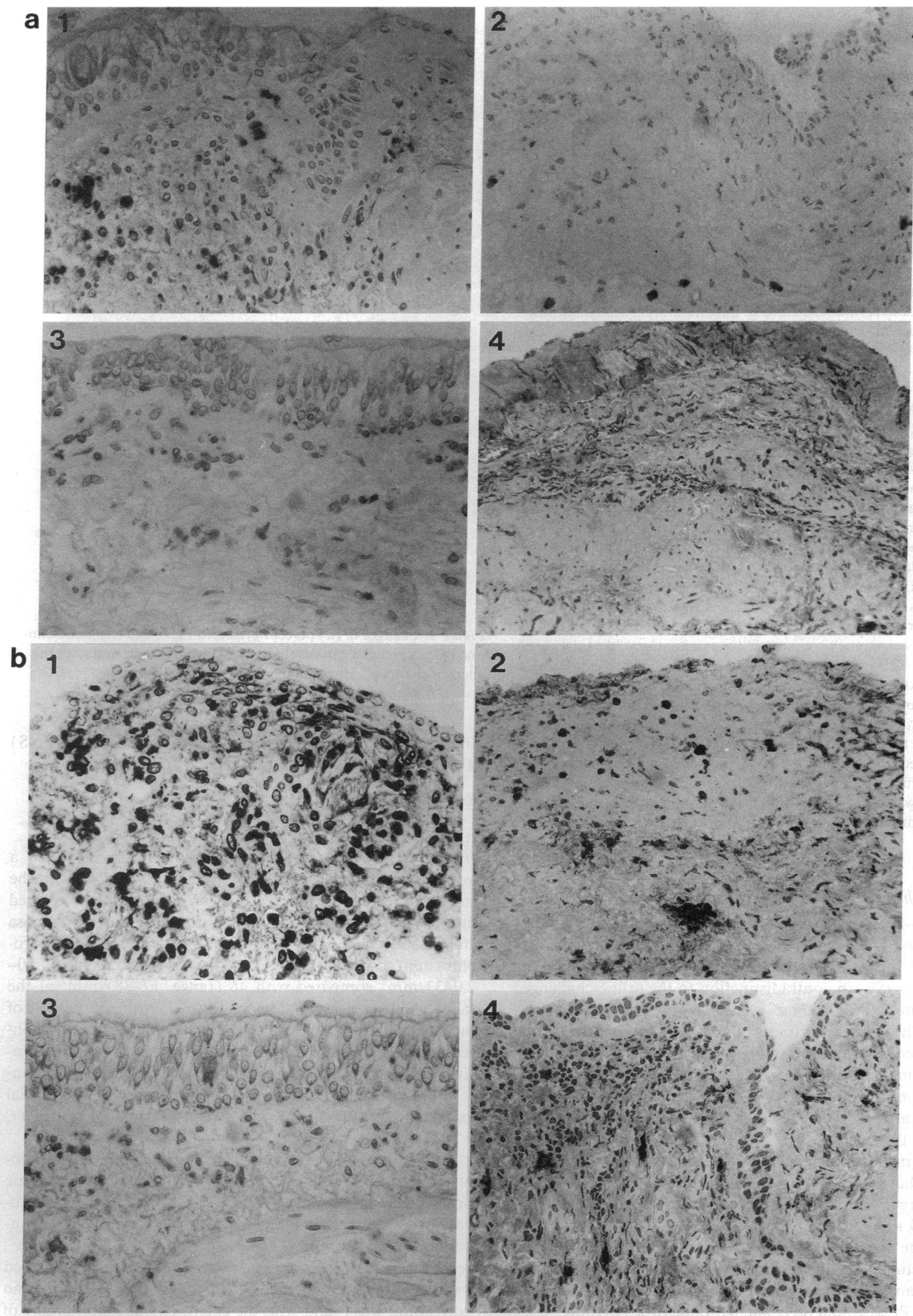

Figure 2. Light microscopy micrographs of GMA-embedded sections immunostained with mAbs to (1) neutrophil elastase, (2) EG2 ${ }^{+}$eosinophils, (3) tryptase ${ }^{+}$mast cells, and (4) $\mathrm{CD}^{+}$lymphocytes from $(a)$ saline-challenged site and $(b)$ allergen-challenged site $(\times 400)$. 

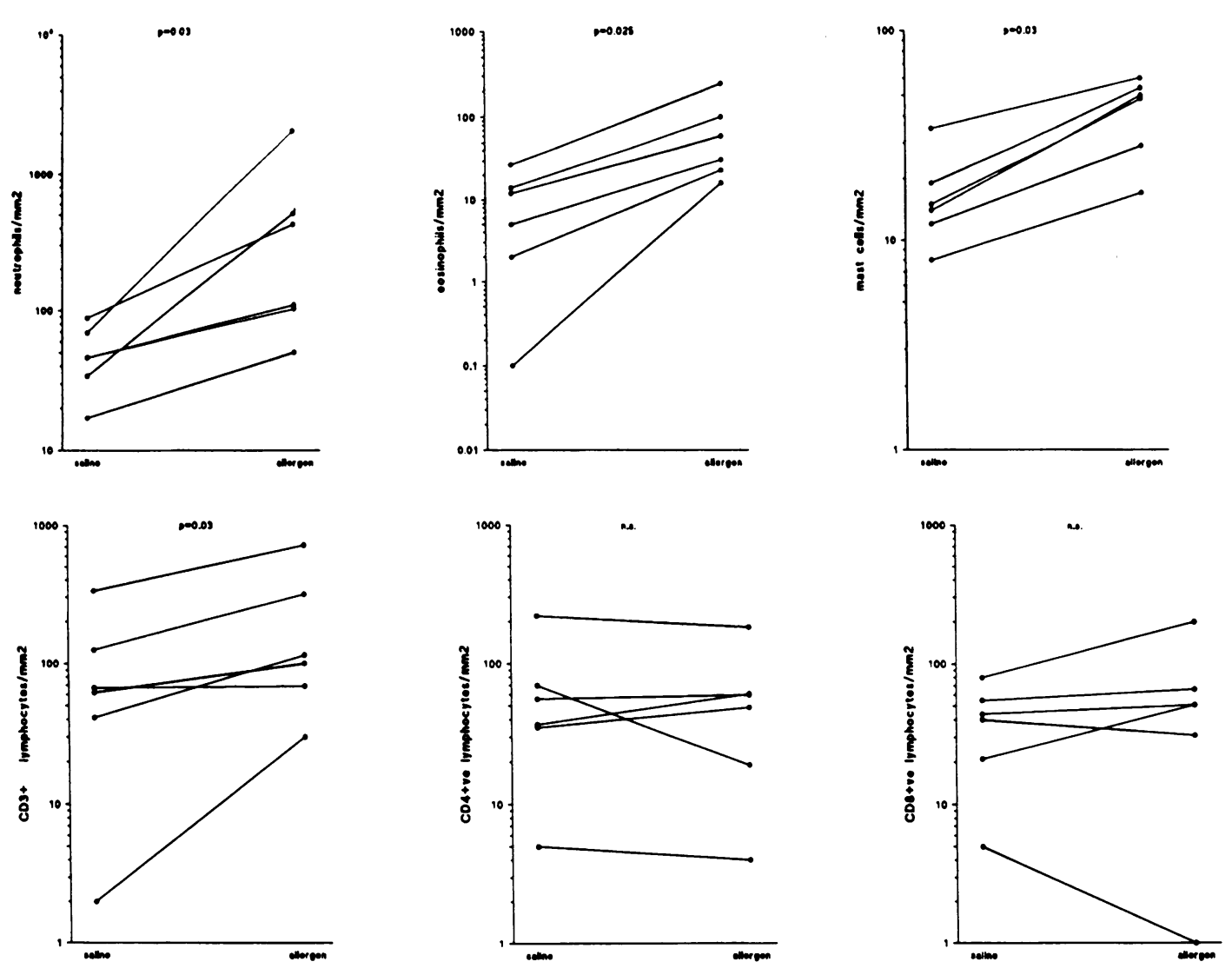

Figure 3. Changes in submucosal leukocytes between saline- and allergen-challenged sites. Horizontal lines denote medians (log scales).

14.5 (range, $8-35) / \mathrm{mm}^{2}$ in the saline-challenged segment to 49 (range, 17-60)/mm $\mathrm{mm}^{2}(P<0.03)$ at the allergen-challenged site.

$\mathrm{T}$ lymphocytes staining positively for CD3 also increased in the submucosa after exposure to allergen but not saline, with counts of 64.5 (range, 2-333) and 107.5 (range, 30-717)/ $\mathrm{mm}^{2}$, respectively $(P<0.03)$, but while both the $\mathrm{CD}^{+}$and $\mathrm{CD} 8^{+}$lymphocyte subsets showed a trend towards increasing this failed to reach statistical significance (45.4 and 59.2 for $\mathrm{CD}^{+}$, and 48.7 and 53.2 for $\mathrm{CD} 8{ }^{+}$lymphocytes).

Electron microscopy. Electron microscopy confirmed the presence of many different cell types infiltrating the airways after allergen challenge, and included platelets (not identified immunohistochemically). In confirmation of the immunohistochemical findings, after allergen exposure, neutrophils depleted in their granules provided additional evidence that these cells were secreting their mediators (Fig. $4 a$ ). Mast cells (Fig. 4 $b$ ) and eosinophils also showed features of degranulation as judged by both classical and piecemeal secretion. Most eosinophils also exhibited reduced electrondensity of the granule crystalloids containing major basic protein (Fig. $4 c$ ). The epithelium and submucosa appeared oedematous as evidenced by separation of columnar and basal cells.

\section{ADHESION MOLECULES}

Glycolmethacrylate sections provided excellent embedding medium to demonstrate immunoreactive epitopes with well-preserved microanatomy and cell morphology. All the mAbs to E-selectin, intercellular (I) CAM-1, and vascular (V)CAM-1 produced clear immunostaining of the mucosal microvasculature. Anti-ICAM-1 also produced scant staining of parts of the basal layer of the bronchial epithelium and of occassional mucosal leukocytes. Both E-selectin and to a greater extent ICAM-
1 were constitutively expressed on the microvascular endothelium, however, only a very low level of VCAM-1 expression was observed.

Differences were apparent when the pattern of immunostaining for the three endothelial adhesion molecules between the allergen and saline challenged bronchi were compared (Fig. $5, a$ and $b$ ). When expressed as a percentage of the total vessel complement, allergen exposure resulted in a median twofold increase in the number of vessels expressing E-selectin from $18.4 \%$ (range, $3.8-35.7 \%$ ) after saline compared with $36.3 \%$ (range, 15.3-68.4\%) after allergen $(P<0.005)$ (Fig. 6). Similarly, allergen also upregulated the expression of ICAM-1 from a basal saline-challenged level of $48.8 \%$ (range, $30.7-62.8 \%$ ) to $70.2 \%$ (range, $38-87.3 \%)(P<0.05)$. This ICAM-1 upregulation was correlated with the decrease in $\mathrm{FEV}_{1}$ observed in the first $24 \mathrm{~h}\left(r_{\mathrm{s}}=0.9 ; P<0.05\right)$. In contrast, allergen provocation had no significant effect on VCAM-1 expression at the 5-6-h time point ( $2.3 \%$ [range, $0-5 \%$ ] vs. $2.4 \%$ [range, $0-12 \%$ ] [NS]).

Both in the epithelium and in the submucosa of the salinechallenged airways occasional leucocytes immunostaining for the cell surface integrin LFA-1 were observed. Exposure to allergen produced a four- to sixfold increase in the number of leukocytes expressing cell surface LFA-1 (Fig. 7), cell medians increasing from 19.9 (range, 2.4-48.4) to 160.5 (range, 36.8$216.4) / \mathrm{mm}^{2}$ in the submucosa $(P<0.01)$ and 0.8 (range, $0-2.4$ ) to 3.8 (range, $2.4-4.2$ )/mm length of basement membrane in the epithelium $(P<0.01)$ (Fig. 8). The allergen-provoked increase in submucosal LFA- $1^{+}$leukocyte infiltrate with allergen exposure correlated with the extent of expression of its ligand ICAM-1 $\left(r_{\mathrm{s}}=0.70\right)$, but not E-selectin or VCAM-1 $\left(r_{\mathrm{s}}\right.$ $\left.=0.30 ; r_{\mathrm{s}}=0.41\right)$. It also correlated with the decrease in FEV, observed in the first day postchallenge $\left(r_{\mathrm{s}}=0.83 ; P<0.05\right)$. 


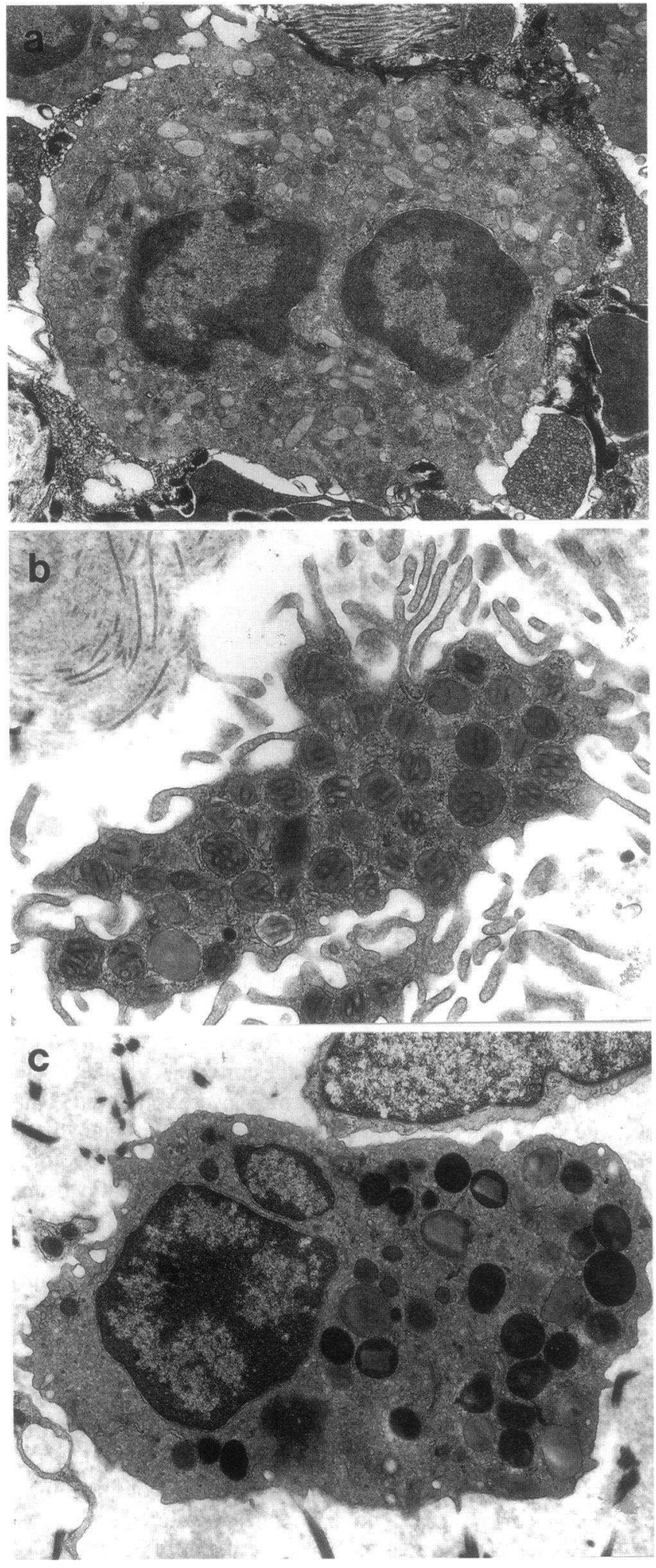

Figure 4. (a) Electron micrograph of a partially degranulated neutrophil within area of edematous bronchial epithelium from allergenchallenged site $(\times 7,000)$. ( $b$ ) Electron micrograph of mast cell with the characteristic scroll-like appearance of granules and some degranulated granules $(\times 17,000)$. (c) Electron micrograph of partially degranulated eosinophil from allergen-challenged site $(\times 8,500)$.

\section{Discussion}

Delivery of allergen directly on the airway surface via the fibreoptic bronchoscope has provided a unique opportunity for defining the cellular events associated with the late asthmatic response 5-6 h postchallenge. Although it was not possible to make detailed measurements of pulmonary function at the same time as the bronchial biopsy, all the subjects experienced a drop in spirometry $24 \mathrm{~h}$ postallergen and an increase in methacholine responsiveness that returned to baseline by $7 \mathrm{~d}$. When compared with the saline-challenged site, allergen also caused a marked increase in the expression of CAMs, specifically E-selectin and ICAM-1, but not VCAM-1. Upregulation of endothelial CAMs was associated with a marked increase in the number of leukocytes expressing the $\beta_{2}$ integrin LFA-1 that correlated with ICAM-1 expression, suggesting a mechanism for leukocyte recruitment. The cellular infiltrate was pleomorphic consisting predominantly of neutrophils and eosinophils but also containing increased numbers of T-cells and mast cells. Electron microscopy confirmed that the neutrophils, eosinophils, and mast cells were activated for mediator secretion. These data provide substantial evidence for leukocyte recruitment and activation as a response to allergen on the asthmatic airways and demonstrate the importance of upregulation of leukocyte-endothelial CAMs as an integral component of this.

A surprising finding in this study was the extensive neutrophil infiltration of the airway 5-6 h after allergen exposure, since the asthmatic response to allergen is frequently cited as being largely eosinophil dependent. While saline-challenged airways contained a few neutrophils, these may have been recruited secondary to nonspecific irritation of the airways by the bronchoscope and saline. After allergen exposure the level of neutrophil influx varied widely between subjects for reasons that are not clear. However, in all cases the cells appeared to be in a secretory mode when assessed both by light and transmission electron microscopy. Although not widely referred to, others have noted neutrophils in BAL 6-48 $\mathrm{h}$ after allergen challenge of asthmatic airways $(19,26)$. Recently, Gundel et al. (27) have suggested that the neutrophil plays a dominant role in the LAR produced at $6 \mathrm{~h}$ by antigen challenge of Ascaris-sensitised monkeys. Neutrophil chemotactic activity has been described in the serum of asthmatics in association with the LAR, but apart from being heat stable and of high molecular weight, this has been poorly characterized (28). A number of well-defined chemoattractants for neutrophils have been described, including $\mathrm{C} 5 \mathrm{a}$ (29), platelet-activating factor (PAF) (30), leukotriene $\mathrm{B}_{4}(31)$, tryptase (32), and members of the IL-8 family (33). However, while a case may be made for each of these contributing to the airway neutrophilia observed, at the time of writing, the role of anyone of these has not been defined. This study has also provided morphological evidence for neutrophil degranulation after allergen challenge. The release of such preformed mediators as elastase, cathepsin $\mathrm{G}$, and myeloperoxidase could contribute to the loosening of the intercellular matrix, thereby facilitating edema formation and detachment of bronchial epithelial cells (34). In addition, the neutrophil is also an important source of broncho- and vasoactive autocoids, including PAF, thromboxane $\mathrm{A}_{2}\left(\mathrm{TxA}_{2}\right)$, together with an array of other prostanoids (35). The neutrophil has been associated with the late phase response associated with occupational asthma caused by isocyanates (18). This study now provides evidence of a role for this cell in the allergen-dependent response. The reason why this cell has been overlooked in the past can probably be explained on the basis that bronchoscopy studies after allergen challenge in asthma have largely been undertaken $24-48 \mathrm{~h}$ postchallenge when the late phase obstructive response has largely recovered, even 
a
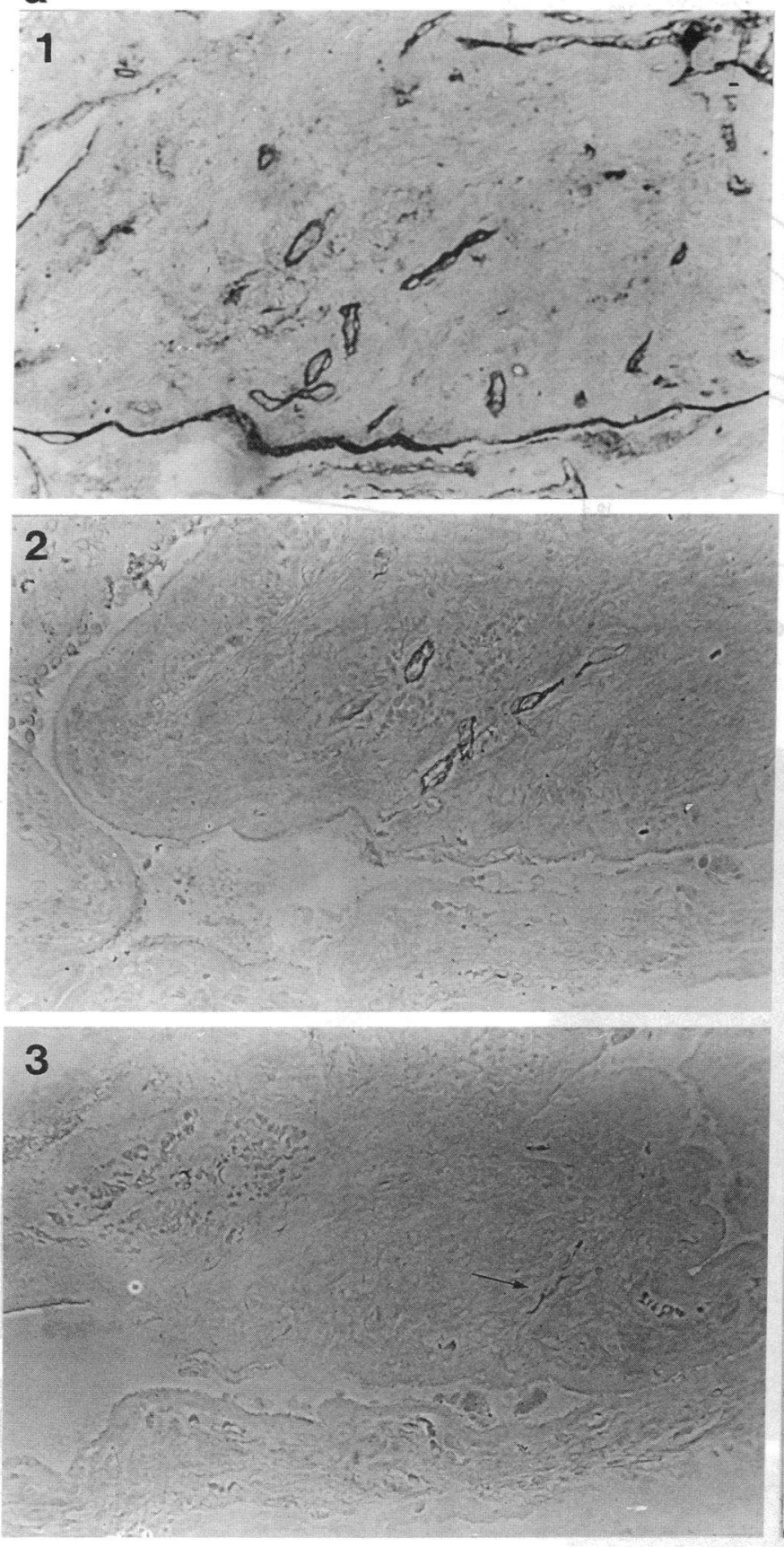

b
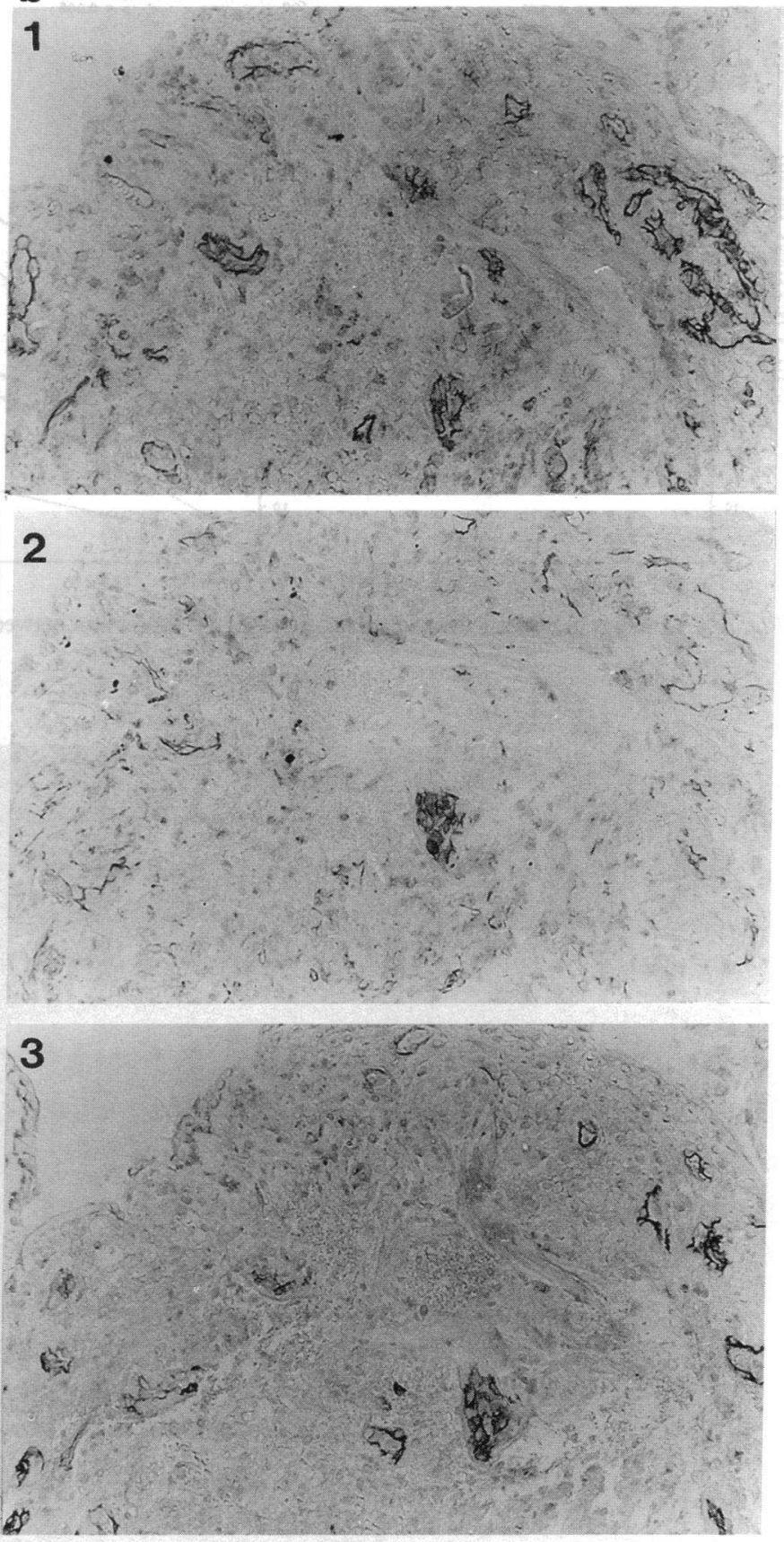

Figure 5. Light microscopy micrographs of GMA-embedded sequential sections immunostained with mAbs to (1) vascular endothelium [EN4], (2) ICAM-1, and (3) E-selectin from $(a)$ saline-challenged site and $(b)$ allergen-challenged site $(\times 400)$.

though the airways remain hyperreactive to agents such as histamine and methacholine.

Consistent with many BAL studies carried out at different time points after allergen challenge $(14,19,26,36)$, we have also observed a significant increase in eosinophil numbers 5-6 $\mathrm{h}$ after segmental challenge with allergen. Although most of the studies have focused at time points 24-96 h postchallenge, Lam et al. (37) and Metzger et al. (19) have reported an airway eosinophilia in BAL at 2 and $4 \mathrm{~h}$, respectively. Durham et al. (17) have also shown a transient early blood eosinopenia soon after allergen challenge compatible with their removal from the circulation by entrapment within the bronchial microvasculature. While in this study we have been able to demonstrate morphological evidence for eosinophil activation, others have shown that allergen challenge is accompanied by release of eosinophilic peroxidase (27) and the secreted form of eosinophil cationic protein (14). At the 5-6-h time point sampled in this study, the magnitude of the eosinophil response was less than that observed for neutrophils although cell number alone may have little to do with either the range or magnitude of vaso- and broncho-active mechanisms contributing to airway dysfunction of the continuing asthmatic response.

The release of mediators from the mast cell is considered to be largely responsible for the EAR, although this mechanism is not thought to contribute to the LAR. We were therefore surprised to find a highly significant increase in the number of 

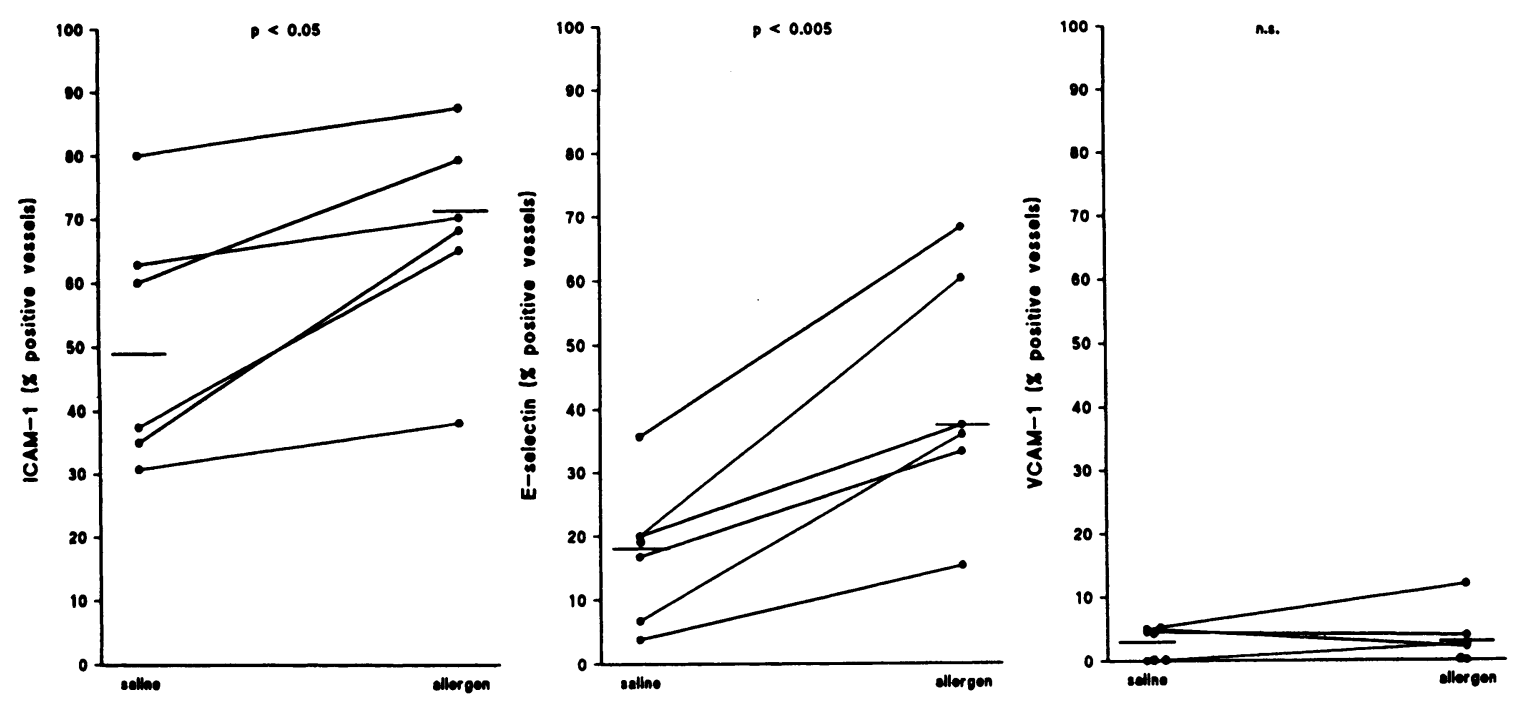

Figure 6. Changes in endothelial cell adhesion molecule expression between saline and allergen-challenged sites. Horizontal lines denote medians.

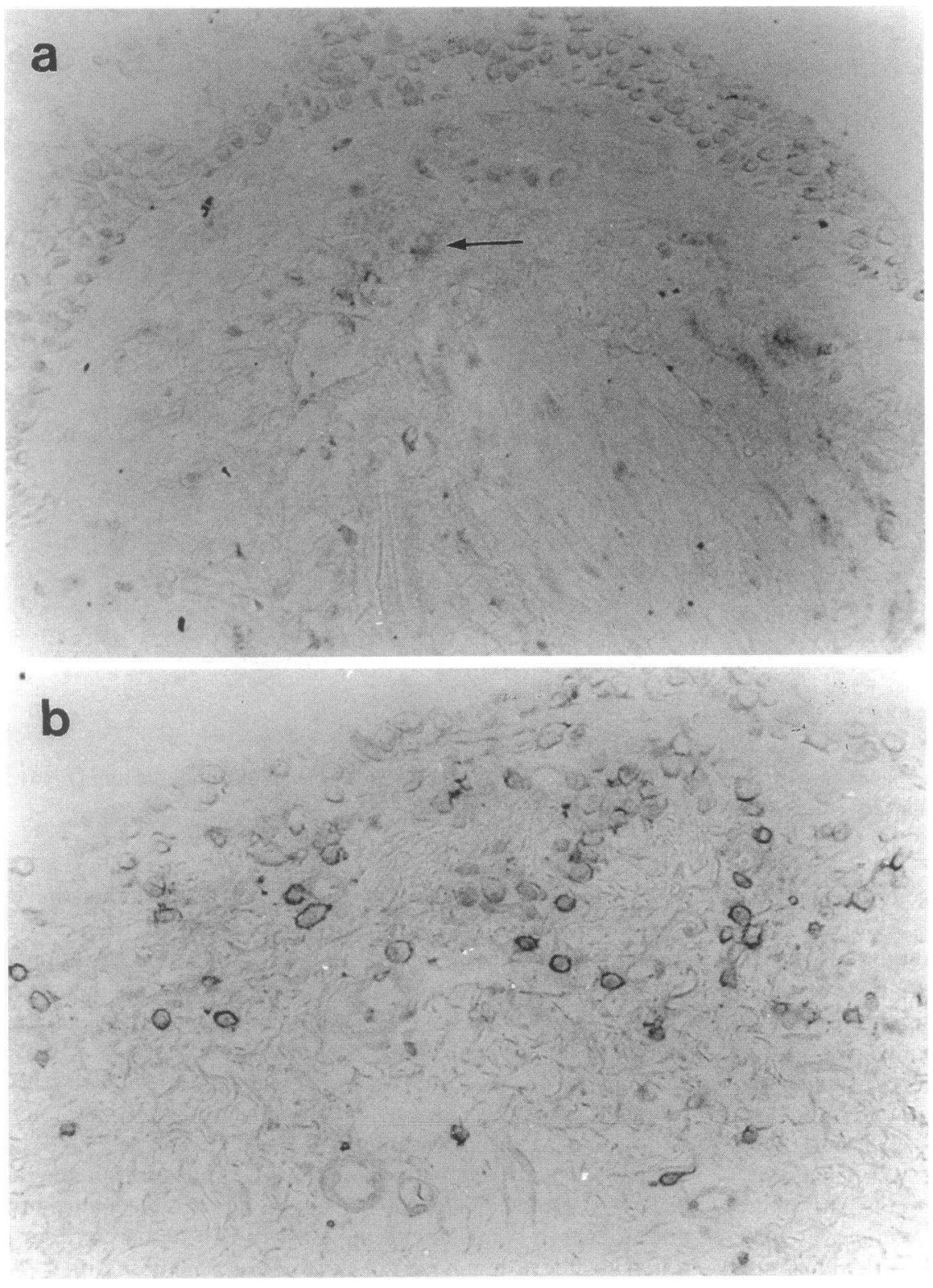

Figure 7. Light microscopy micrographs of GMA-embedded sections immunostained with mAb to LFA-1 from $(a)$ saline-challenged site and $(b)$ allergen-challenged site $(\times 400)$. 


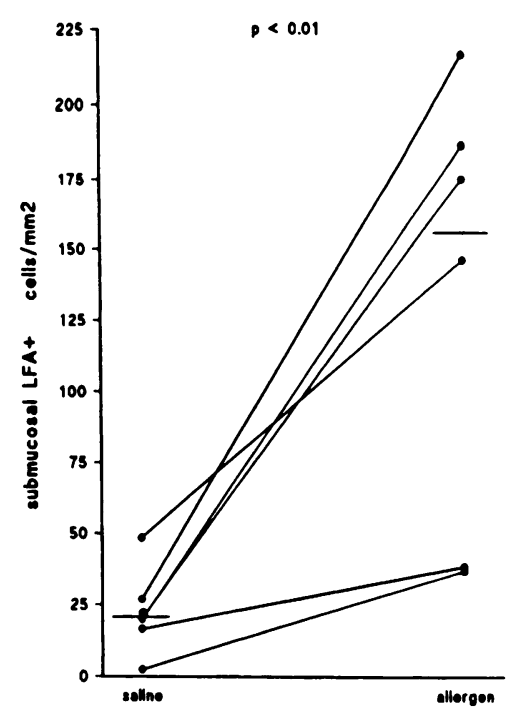

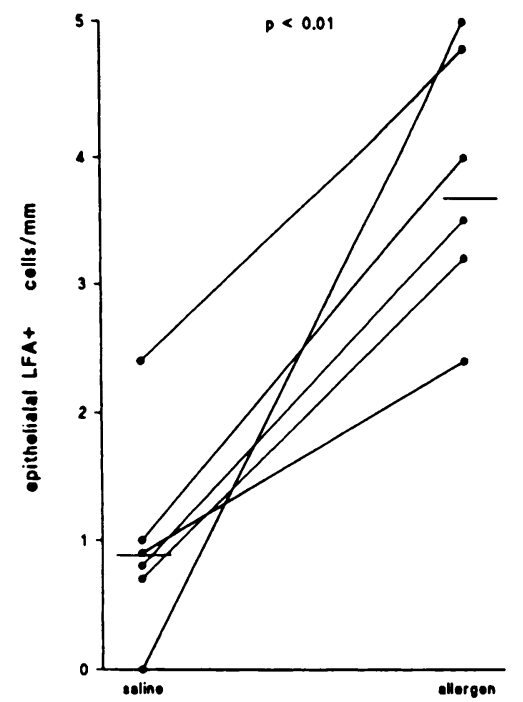

Figure 8. Changes in $(a)$ submucosal and $(b)$ epithelial LFA- ${ }^{+}$leukocytes between saline- and allergenchallenged sites. Horizontal lines denote medians. mast cells, identified by their granule content of tryptase, that had moved into the submucosa 5-6 $\mathrm{h}$ postallergen. It seems most unlikely that these cells are recruited from the circulation or matured rapidly from resident mast cell precursors. A more plausible explanation for the increase in mast cell number is migration of these cells to the airway surface from deeper in the airway wall, where they are more likely to be activated by allergen. Not much is known about mast chemotaxis, although recently Thompson et al. (38) have shown that laminin and fibronectin fragments are chemoattractant to cultured murine mast cells. In Bazenji greyhound dogs, Turner et al. (39) have shown that mast cell numbers increase in the superficial aspects of the airway within $1 \mathrm{~h}$ of local allergen stimulation, indicating that rapid migration of mast cells in response to allergen is possible. Crimi et al. (40) have also observed an increase in submucosal mast cell numbers $24 \mathrm{~h}$ but not $4 \mathrm{~h}$ after allergen inhalation in asthmatics developing a late-phase reaction. Interestingly, Diaz et al. (26) noticed that there was a decrease in their BAL mast cell numbers in allergen-challenged bronchi at $7 \mathrm{~h}$ postchallenge, and suggested that this might be due to these cells being retained by increased adherence to acutely inflammed sites within the bronchial mucosa. The significance of the apparent mucosal mast cell hyperplasia at this time point clearly requires more careful evaluation since mast cells, in addition to neutrophils and eosinophils, are an important source of mediators, including cytokines.

In addition to an influx of mediator-secreting cells, allergen provocation resulted in an influx of $\mathrm{CD}^{+} \mathrm{T}$ lymphocytes. $\mathrm{Re}-$ cruitment of $\mathrm{T}$ lymphocytes has been clearly described in association with allergen-induced late phase reactions in the skin $(41,42)$, with a case being presented that these cells augment the allergic inflammatory response through secretion of specific cytokines (43). A subset of helper T cells, designated Th 2 , respond to allergen by secreting IL-3, IL-4, IL-5, IL-6, and GM-CSF involved in mast cell growth and priming (IL-3, IL4), eosinophil recruitment and priming (IL-5, GM-CSF), and isotype switching of B cells to IgE synthesis (IL-4, IL-6). Thus, it seems likely that the $T$ cell infiltrate seen $6 \mathrm{~h}$ after allergen instillation represents a mechanism for amplifying and prolonging the inflammatory response.

The mechanisms whereby leukocytes are selectively removed from the microvasculature and recruited into sites of inflammation have recently been clarified with the identifica- tion of the roles played by specific leukocyte-endothelial adhesion molecules. This study has shown an upregulation of E-selectin and ICAM-1 but not VCAM-1 5-6 h after allergen challenge. Previous methods attempting to quantify adhesion molecules expression in tissue biopsies have relied upon semiquantitative subjective grading of immunoreactivity, which is subject to considerable intraobserver variation. To circumvent this we opted to express CAM expression on the endothelium as a percentage of the total vessel complement. An alternative approach would be to count the number of endothelial cells expressing a particular CAM, but this would require immunoelectron microscopy to produce reliable results. On human umbilical vein endothelial cells in vitro, E-selectin is upregulated by IL- 1 and TNF $\alpha$, peaking in expression within $4 \mathrm{~h}$ of stimulation (44). Although ICAM-1 and VCAM-1 have similar time courses of upregulation in vitro to each other, in our study only the former showed any such increase in expression. The mechanisms responsible for the dissociation of ICAM-1 from VCAM1 expression in vivo are not at present clear. This pattern of expression in vivo is in agreement with that observed in the skin of atopic subjects $6 \mathrm{~h}$ after intradermal allergen injection (45). Interestingly, Bentley et al. (46) have recently reported an increased bronchial mucosal expression of VCAM-1 $24 \mathrm{~h}$ postallergen inhalation. Together these observations might be interpreted as an early upregulation of E-selectin and ICAM-1 being responsible for the mixed eosinophil, neutrophil, and $T$ cell response at 5-6 h, while VCAM-1 increasing up to $24 \mathrm{~h}$ may account for the more selective eosinophil and $\mathrm{T}$ cell response at this later time point consequent upon an interaction with the leukocyte integrin VLA-4 ( $\alpha 4 \beta 1)$ (47). The findings of upregulated E-selectin and ICAM-1 are similar to those of Wegner et al. (48) and Gundel et al. (49), who have shown that mAbs to ICAM-1 and E-selectin, respectively, attenuated leukocyte recruitment and the disordered airway function observed in Ascaris-sensitised monkeys after allergen exposure.

The mechanisms causing upregulation of adhesion molecules on the airway microvasculature after allergen exposure are at present speculative. In vitro studies point to an important role played by various stimulatory cytokines. A number of studies have shown that bone marrow-derived murine mast cells and mast cell lines generate a range of cytokines, including IL-3, IL-4, IL-5, IL-9, and TNF $\alpha$, after IgE-dependent stimulation (50), and in human bone marrow, Piccinni et al. (51) 
have described a population of $\mathrm{Fc}_{\mathrm{E}} \mathrm{RI}$-bearing non-B-non- $\mathrm{T}$ cells that generate a similar spectrum of cytokines upon receptor cross-linkage. Walsh et al. (52) have reported the presence of preformed TNF $\alpha$ in mast cells of human skin and its release with allergen challenge, and together with Klein et al. (53), have suggested that upregulation of E-selectin on endothelial cells by antigen in human skin organ culture relates to the release of TNF $\alpha$ from IgE-triggered mast cells. Similarly, Bradding et al. (54) have recently reported the localization and immunologic release of IL-4 from both human lung and skin mast cells. IL- 4 is a selective stimulus for upregulating the expression of VCAM-1 on endothelial cells (55), and as such might be implicated in the selective recruitment of eosinophils and $\mathrm{T}$ cells but not neutrophils $24 \mathrm{~h}$ after allergen exposure. Finally, we have also observed a correlative increase of LFA-1 ${ }^{+}$ leukocytes into the submucosa and epithelium of the bronchial biopsies at the allergen-challenged site. This probably represents most of the infiltrating leukocytes that used this $\beta 2$ integrin as one of adhesion molecules to adhere to and transmigrate from the circulation into the bronchial mucosa.

The decrease in baseline $\mathrm{FEV}_{1}$ and increase in methacholine responsiveness of the airways $24 \mathrm{~h}$ after segmental challenge with allergen suggests that the challenge initiated events that extended beyond the local site by that time point. For technical reasons it was not possible to obtain reliable $\mathrm{FEV}_{1}$ readings $6 \mathrm{~h}$ postallergen instillation in four subjects, although in two, in whom good measurements were obtained, their baseline $\mathrm{FEV}_{1}$ had not fallen at $6 \mathrm{~h}$. This suggests that the uniform changes in airway dysfunction observed at $24 \mathrm{~h}$ related to neural reflex mechanisms or more likely a secondary systemic response. It would clearly be of interest to observe the biopsy appearance of the saline challenged site at $24 \mathrm{~h}$ for comparison with the minimal changes seen at $6 \mathrm{~h}$.

In conclusion, we have shown that at 5-6 $\mathrm{h}$ after the exposure of allergic asthmatic airways to specific allergen, there occurs an upregulation of E-selectin and ICAM- 1 that is accompanied by an influx of LFA- $1^{+}$leukocytes into the submucosa and epithelium. These cells include neutrophils and eosinophils, whose mediators could account for the reduced airway caliber and BHR associated with allergen-induced LAR. A knowledge of the importance of the mechanisms leading to adhesion molecule upregulation and the recruitment of inflammatory cells in this model presents an exciting opportunity for the development of new pharmacological agents for treatment of allergen-triggered asthma.

\section{Acknowledgments}

This work was supported by a Medical Research Council Programme grant (PG 860 4034). S. Montefort is a Commonwealth Scholar.

\section{References}

1. Dunnill, M. S. 1960. The pathology of asthma, with specific reference to changes in the bronchial mucosa. J. Clin. Pathol. 13:27-33.

2. Beasley, R., W. R. Roche, J. A. Roberts, and S. T. Holgate. 1989. Cellular events in the bronchi in mild asthma and after bronchial provocation. Am. Rev. Respir. Dis. 139:806-817.

3. Djukanovic, R., J. W. Wilson, K. M. Britten, S. J. Wilson, A. F. Walls, W. R. Roche, P. H. Howarth, and S. T. Holgate. 1990. Quantitation of mast cells and eosinophils in the bronchial mucosa of symptomatric and healthy control subjects using immunohistochemistry. Am. Rev. Respir. Dis. 142:863-871.

4. Jeffery, P. K., A. J. Wardlaw, F. C. Nelson, J. V. Collins, and A. B. Kay. 1989. Bronchial biopsies in asthma: an ultrastructural, quantitative study and correlation with hyperreactivity. Am. Rev. Respir. Dis. 140:1745-1753.

5. Laitinen, L. A., M. Heino, A. Laitenen, T. Kava, and T. Hauhtela. 1985.
Damage to the airway epithelium and bronchial reactivity in patients with asthma. Am. Rev. Respir. Dis. 131:599-606.

6. Roche, W. R., R. Beasley, J. H. Williams, and S. T. Holgate. 1989. Subepithelual fibrosis in the bronchi of asthmatics. Lancet. i:520-524.

7. Bousquet, J., P. Chanez, J. Y. Lacoste, G. Barneon, N. Ghavanian, I. Enander, P. Venge, S. Ahlstedt, J. Simony-Lafontaine, P. Godard, and F. B. Michel. 1990. Eosinophilic inflammation in asthma. N. Engl. J. Med. 323:10331039.

8. Corrigan, C. J., and A. B. Kay. 1990. CD4 T-lymphocyte activation in acute severe asthma: relationship to disease severity and atopic status. Am. Rev. Respir. Dis. 141:970-977.

9. Booij-Nord, H., N. G. M. Orie, and K. De Vries. 1971. Immediate and late bronchial obstructive reactions to inhalation of house dust and protective effects of disodium cromoglycate and prednisolone. J. Allergy Clin. Immunol. 48:344354.

10. Pepys, J., and J. F. Hutchcroft. 1975. Bronchial provocation tests in aetiologic diagnosis and analysis of asthma. Am. Rev. Respir. Dis. 112:829-859.

11. Howarth, P. H., S. R. Durham, T. H. Lee, A. B. Kay, M. K. Church, and S. T. Holgate. 1985. Influence of albuterol, cromolyn sodium and ipratropium bromide on the airways and circulating mediator responses to allergen bronchial provocation in asthma. Am. Rev. Respir. Dis. 132:986-992.

12. Wenzel, S. E., A. A. Fowlerand, and L. B. Schwartz. 1988. Activation of pulmonary mast cells by bronchoalveolar allergen challenge: in vivo release of histamine and tryptase in atopic subjects with and without asthma. Am. Rev. Respir. Dis. 137:1002-1008.

13. Casale, T. B., D. Wood, H. B. Richerson, B. Zehr, D. Zavala, and G. W. Hunninghake. 1987. Direct evidence of a role for mast cells in the pathogenesis of antigen-induced bronchoconstriction. J. Clin. Invest. 80:1507-1511.

14. De Monchy, J. G., J. J. Keyzer, and H. F. Kauffman. 1986. Histamine in late asthmatic reactions following house dust mite inhalation. Agents Actions. 16:252-255.

15. Lai, C. K. W., R. Beasley, and S. T. Holgate. 1989. The effect of an increase in inhaled allergen dose after terfanidine on the occurrence and magnitude of the late asthmatic response. Clin. Exp. Allergy. 19:209-16.

16. Booij Nord, H., K. De Vries, S. J. Sluiter, and N. G. M. Orie. 1972. Late bronchial obstructive reaction in experimental inhalation of house dust extract. Clin. Allergy. 2:43-61.

17. Durham, S. R., W. O. Cookson, J. Faux, C. F. Craddock, and M. K. Benson. 1989. Basic mechanisms in allergen-induced late asthmatic responses. Clin. Exp. Allergy. 19:117a (Abstr.)

18. Fabbri, L. M., P. Boschetto, E. Zocca, G. Milani, F. Pivirotto, M. Plebani, A. Burlina, B. Licata, and C. E. Mapp. 1987. Bronchalveolar neutrophilia during late asthmatic reactions induced by toluene diisocyanate. Am. Rev. Respir. Dis. 136:36-42.

19. Metzger, W. J., H. B. Richardson, K. Worden, H. Monnick, and G. W. Hunninghake. 1986. Bronchoalveolar lavage of allergic asthmatic patients following allergen bronchoprovocation. Chest. 89:477-83.

20. Pepys, J., R. J. Davies, A. B. X. Breslin, D. J. Hendricks, and B. J. Hutchcroft. 1974. The effect of inhaled beclomethasone dipropionate (Becotide) and sodium cromoglycate on asthmatic reactions in provocation tests. Clin. Allergy. 4:413-424.

21. Britton, J. R., S. P. Hanley, and A. E. Tattersfield. 1987. The effect of an oral leukotriene $\mathrm{D}_{4}$ antagonist L-649,923 on the response to inhaled antigen in asthma. J. Allergy Clin. Immunol. 79:811-816.

22. Chai, H., R. S. Fan, L. A. Frolish, D. A. Mathison, J. A. Mclean, R. R. Rosenthal, A. L. Sheffer, S. A. Spector, and R. G. Townley. 1975. Standardisation of bronchial inhalation challenge procedures. J. Allergy Clin. Immunol. 56:323327.

23. Djukanović, R., J. Wilson, C. Lai, P. H. Howarth, and S. T. Holgate. 1991. The safety aspects of fibreoptic bronchoscopy lavage and endobronchial biopsy in asthma. Am. Rev. Respir. Dis. 143:772-777.

24. Britten, K., and W. R. Roche. 1992. Immunohistochemistry of resin-embedded bronchial biopsies. Clin. Exp. Allergy. 22:123. (abstr.)

25. Montefort, S., I. H. Feather, S. Wilson, T. H. Lee, D. O. Haskard, S. T. Holgate, and P. H. Howarth. 1992. The expression of leucocyte-endothelial adhesion molecules is increased in perennial rhinitis. Am. J. Resp. Cell Mol. Biol. 7:393-398.

26. Diaz, P., C. Gonzalez, F. R. Galleguillos, P. Ancic., O. Cromwell, D. Shepherd, S. R. Durham, G. J. Gleich, and A. B. Kay. 1989. Leucocytes and mediators in bronchoalveolar lavage during allergen-induced late-phase asthmatic reactions. Am. Rev. Respir. Dis. 139:1383-1389.

27. Gundel, R. H., C. D. Wegner, and L. G. Letts. 1992. Antigen-induced acute and late-phase responses in primates. Am. Rev. Respir. Dis. 146:369-373.

28. Nagy, L., T. H. Lee, and A. B. Kay. 1982. Neutrophil chemotactic activity in antigen-inducedlate asthmatic reactions. N. Engl. J. Med. 306:497-501.

29. Ward, P. A., and L. J. Newman. 1969. A neutrophil chemotactic factor from human C5. J. Immunol. 102:93-99.

30. Wardlaw, A. J., R. Moqbel, O. Cromwell, and A. B. Kay. 1986. Platelet activating factor: a potent chemotactic and chemokinetic factor for human eosinophils. J. Clin. Invest. 78:1701-1706.

31. Bisgaard, R., S. Helqvist, L. Boudet, P. Venge, R. Dahl, and J. Sonder- 
gaard. 1986. Chemotactic activity of LTB4 in man. Allergy (Cph.). 41:365-372.

32. Teran, L. M., A. F. Walls, M. K. Church, and S. T. Holgate. 1992. Human mast cell tryptase is chemotactic for neutrophils. Eighth International Congress of Immunology. Budapest, Hungary W-27, 17. (Abstr.).

33. Arsen, C. G., A. G. Anderson, E. Appella, J. J. Oppenheim, and K. Masushima. 1989. The neutrophil-activating protein [NAP-1] is also chemotactic for T lymphocytes. Science (Wash. DC). 243:1464-1466.

34. Rickard, K., and S. Rennard. 1989. Neutrophil elastase causes detachment of bronchial epithelial cells from extracellular matrix. Am. Rev. Respir. Dis. 139[Suppl]:406a. (Abstr.)

35. Venge, P. 1985. Eosinophil and neutrophil granulocytes in asthma. Curr. Clin. Pract. Ser. 25:21-37.

36. Liu, M. C., W. C. Hubbard, D. Proud, B. A. Stealey, S. J. Galli, A. KageySobotka., E. R. Bleeker, and L. M. Lichenstein. 1991. Immediate and late inflammatory responses to ragweed antigen challenge of the peripheral airways in allergic asthmatics: cellular, mediator and permeability changes. Am. Rev. Respir. Dis. 144:51-58.

37. Lam, S., J. LeRiche, D. Phillips, and M. Chan-Yeung. 1987. Cellular and protein changes in bronchial lavage fluid after late asthmatic reaction in patients with red cedar asthma. J. Allergy Clin. Immunol. 80:44-50.

38. Thompson, H. L., L. Thomas, and D. D. Metcalfe. 1993. Murine mast cells attach to and migrate on laminin-, fibronectin-, matrigel-coated surfaces in response to FceRI-mediated signals. Clin. Exp. Allergy. 23:270-275.

39. Turner, C. R., J. Kolbe, and E. W. Spannhake. 1988. Rapid increase in mast cell numbers in canine central and peripheral airways. J. Appl. Physiol. $65: 445-451$.

40. Crimi, E., M. Chiaramondia, M. Milanese, A. M. Rossi, and V. Brusasco. 1991. Increased numbers of mast cells in bronchial mucosa after late-phase asthmatic response to allergen. Am. Rev. Respir. Dis. 144:1282-1286.

41. Frew, A. J., and A. B. Kay. 1988. The relationship between infiltrating $\mathrm{CD}^{+}$lymphocytes, activated eosinophils and the magnitude of the allergen-induced late-phase cutaneous reaction. J. Immunol. 141:4158-4164.

42. Durham, S. R., V. A. Varney, M. Gaga, M. R. Jacobsen, A. J. Frew, and A. B. Kay. 1991. Immunotherapy suppresses T lymphocyte infiltrate in the cutaneous late-phase reaction. J. Allergy Clin. Immunol. 87:299. (Abstr.)

43. Kay, A. B., P. M. Henson, G. W. Hunnighake, C. Irvin, L. M. Lichenstein, and J. A. Nadel. 1989. Cellular mechanisms. In The role of Inflammatory Processes in Airway Hyperresponsiveness S. T. Holgate, editor Blackwell Scientific Publications, Oxford. 151-178.

44. Bevilacqua, M. P., S. Stengelin, M. A. Gimbrone, and B. Seed. 1989. ELAM-1: an inducible receptor for neutrophils related to complement regulatory proteins and lectins. Science (Wash. DC). 243:1160-1164.
45. Kyan Aung, U., D. O. Haskard, R. N. Poston, M. Thornhill, and T. H. Lee. 1991. ELAM-1 and ICAM-1 mediate the adhesion of eosinophils to endothelial cells in vitro and are expressed by endothelium in allergic cutaneous inflammation in vivo. J. Immunol. 146:521-528.

46. Bentley, A. M., S. R. Durham, D. S. Robinson, O. Cromwell, A. B. Kay, and A. J. Wardlaw. 1992. Expression of the endothelial and leucocyte adhesion molecules ICAM-1, E-selectin and VCAM-1 in the bronchial mucosa in steady state asthma and allergen-induced asthma. Thorax. 47:852. (Abstr.)

47. Walsh, G. M., J. J. Mermod, A. Hartnell, A. B. Kay, and A. J. Wardlaw. 1991. Human eosinophil, but neutrophil, adherence to IL-1-stimulated human umbilical vascular endothelial cells is $\alpha 4 \beta 1$ [VLA-4] dependent. J. Immunol. 146:3419-3423.

48. Wegner, C. D., R. H. Gundel, P. Reilly, N. Haynes, L. G. Letts, and R. Rothlein. 1990. ICAM-1 in the pathogenesis of asthma. Science (Wash. DC) 247:416-418.

49. Gundel, R. H., C. D. Wegner, C. A. Torcellini, C. C. Clarke, N. Haynes, R. Rothlein, C. W. Smith, and L. G. 1991. ELAM-1 mediates antigen-induced acute airway inflammation and late-phase obstruction in monkeys. J. Clin. Invest. 88:1407-1411.

50. Plautt, M., J. H. Pierce, C. J. Watson, J. Hanley-Hyde, R. P. Nordan, and W. E. Paul. 1989. Mast cell lines produce lymphokines in response to cross-linkage of FceRI or to calcium ionophores. Nature (Lond.). 339:64-67.

51. Piccinni, M. P., D. Macchia, P. Parronchi, M. G. Giudizi, D. Bani, R. Alterini, A. Grossi., M. Ricci, E. Maggi, and S. Romagnani. 1991. Human bone marrow non-B, non-T cells produce interleukin 4 in response to cross-linkage of Fc $\epsilon$ and Fc $\gamma$ receptors. Proc. Natl. Acad. Sci. USA. 88:8656-8660.

52. Walsh, L. J., G. Trinchieri, H. A. Waldorf, D. Whitaker, and G. F. Murphy. 1991. Human dermal mast cells contain and release tumor necrosis factor $\alpha$, which induces endothelial leukocyte adhesion molecule 1. Proc. Natl. Acad. Sci. USA. 88:4220-4224.

53. Klein, L. M., R. M. Lavker, W. L. Matis, and G. F. Murphy. 1989 Degranulation of human mast cells induces an endothelial antigen central to leucocyte adhesion. Proc. Natl. Acad. Sci. USA. 86:8972-8976.

54. Bradding, P., I. Feather, P. Howarth, R. Meuller, J. A. Roberts, K. Britten, T. Hunt, Y. Okayama, C. Heusser, G. Bullock, M. K. Church, and S. T. Holgate. 1992. Interleukin 4 is localized to and released by human mast cells. J. Exp. Med. 176:1381-1386.

55. Thornhill, M. H., S. M. Wellicome, D. L. Mahiouz, J. S. Lanchbury, U. Kyan Aung, and D. O. Haskard. 1991. Tumour necrosis factor combines with IL-4 or IFN $\gamma$ to selectively enhance endothelial cell adhesiveness for T cells. $J$. Immunol. 146:592-598. 